\title{
Transitivity Shift in the Translated Official Website of Indonesian Ministry of Health
}

\author{
DELIA ZUHERA \\ University of Sumatera Utara, Abdul Hakim street, Padang Bulan, Medan Baru, Medan, \\ Indonesia \\ deliazuhera28@gmail.com
}

\begin{abstract}
The objectives of this research are to depict the shift of transitivity that happen brought about by applying interpretation strategies in the translation on the site of Indonesian Ministry of Health. This research is Transitivity Shift In The Translated Official Website Of Indonesian Ministry Of Health. The samples of the research were clauses under the classification of experiential capacity that experience a shift in transitivity. The data were gathered by using the observation strategy. This strategy specifically selects articles that regulate Covid-19 and their translations in English. It has to carefully read every provision in the source language, then finding transitivity shifts by grouping it according to the experience capacity function. This research was analyzed by qualitative descriptive method and Systemic Functional Linguistic (SFL) approach. The findings showed that there are the transitivity shifts in the articles that published on $20^{\text {th }}$ July and $11^{\text {th }}$ September 2020. In conclusion, the transitivity shift in the analyzed articles, there are transitivity shifts on existential to verbal, material to relational, behavioral to material, verbal to relational and relational to existential. Nonetheless, there is no shift involving mental process in the two articles.
\end{abstract}

Keywords: covid-19, indonesian ministry of health, official website, shift, transitivity 


\title{
Pergeseran Transitivitas pada Terjemahan Website Resmi Kementerian Kesehatan Republik Indonesia
}

\begin{abstract}
Abstrak
Penelitian ini bertujuan untuk menggambarkan pergeseran transitivitas yang terjadi akibat penerapan strategi interpretasi dalam penerjemahan di situs Kementerian Kesehatan Republik Indonesia. Penelitian ini adalah Pergeseran Transitivitas Pada Terjemahan Website Resmi Kementerian Kesehatan Republik Indonesia. Sampel penelitian ini adalah klausa yang termasuk dalam klasifikasi experiential capacity yang mengalami pergeseran transitivitas. Pengumpulan data dilakukan dengan menggunakan strategi observasi. Strategi ini memilih secara spesifik artikel yang mengatur tentang Covid-19 dan terjemahannya dalam bahasa Inggris. Pada strategi ini harus membaca dengan cermat setiap ketentuan dalam bahasa sumber, lalu menemukan pergeseran transitivitas dengan mengelompokkan kalimat sesuai fungsi kapasitas eksperiensial. Penelitian ini dianalisis dengan metode deskriptif kualitatif dan menggunakan pendekatan Systemic Functional Linguistic (SFL). Temuan menunjukkan bahwa ada beberapa pergeseran transitivitas dalam artikel yang diunggah pada tanggal 20 Juli dan 11 September 2020 ini. Kesimpulannya, pergeseran transitivitas dalam artikel yang dianalisis, terdapat pergeseran transitivitas existential ke verbal, material ke relational, behavioral ke material, verbal tke relational dan relational ke existential. Meskipun demikian, tidak ada pergeseran yang melibatkan proses mental dalam kedua pasal tersebut.
\end{abstract}

Kata kunci: covid-19, kementrian kesehatan, website resmi, pergeseran, transitivitas

\section{INTRODUCTION}

Translation exercises consistently includes between two language. In interpretation exercises, interpreters should know about language and culture, both in the source language and the objective language. This is vital on the grounds that in the interpretation cycle, interpreters are required not exclusively to have the option to decipher the language, yet in addition to have the option to pass on a decent message, remembering for terms of style and culture. The above statement is the same as that of Frauengelder and Schriefers in Tzou, Vaid, and Chen $(2017$, p. 632), which points out that translation is basically a linguistic phenomenon, involving the lexical mapping and syntactic code of two languages, and the reformulation of the source language idea 
Issues in translation are brought about by three components, specifically 1) the ability of interpreters (language, culture, move) and abilities in the field of interpretation 2) phonetic variables on the grounds that every language has an alternate language framework and 3) social elements (Sabrina, 2015). These components can prompt a move. This is an effort in the translation process because of the need to transfer text between languages (Whyatt, Stachowiak, \& KajzerWietrzny, 2016).

One of the contributions of SFL is in the translating a text, either online or printed text. The translation itself involves replacing a text from one language to another language. It also carries or transfers meaning containing in the source text into the target text. Discussing about meaning and referring to SFL theory, experiential or ideational function can be one of the functions that needs to be considered in the translation since it represents experience or idea conveyed in the text. The text itself covers transitivity which realises meaning relevant to the context of situation by emphasizing to the function of clauses in the text. It means that transitivity is the meaning of the clauses and represents a model of experience (Halliday in Tinambunan, Santoso, \& Tangkas, 2019).

As clarification previously, transitivity is the cycle of the ideational capacity. Transitivity is fundamental for the philosophical importance of the semantics and the field of the setting of the circumstance. The transitive provision can be separated into three segments. These are the types of processes, the functions of the participants and the circumstances. Truly, it is a cycle of rationalistic commitment between the nominal group and the clause. It is a continuous process, crossing the boundaries between different languages: it started in ancient Greek and was later transferred to English and other languages of modern Europe (Halliday, 2002). From the clarification above, it tends to be reasoned that the adjustment in transitivity is because of the process shift. They can't be isolated in light of the fact that they are work components of the provision addressing the exchange. Each time a process shift happens, a transitivity shift will be applied.

The researcher is keen on noticing the transitivity shift in one of deciphered sites, specifically the authority site of the Ministry of Health of the Republic of Indonesia. The researcher is pulled in to choose this site as the object of this exploration in light of the SARS-CoV2 pandemic that is as of now clearing the world, including Indonesia. For this situation, the part of the Ministry of Health here is exceptionally imperative to deal with and give training to the public identified with the counteraction of Corona Virus, one of which is by continually 
giving data about wellbeing convention including keeping a distance, wearing a mask, maintaining a strategic distance from groups and washing hands. Further, the service of wellbeing additionally utilizes its authority site as a method for the general population to see advancement and data identified with the Covid. Hence, to see if the article was passed on effectively in the objective content, the researcher is keen on inspecting the transitivity move that happened between Bahasa Indonesia and English in the articles. The acknowledgment that there may be a shift in the accentuation on importance or message passed on from ST to TT. The language can be connected in terms of meaning, form, and expression to realize this meaning, which is natural based on social context (Rahmawati, 2018).

\section{METHOD}

The source of the data for this research was articles about the Covid-19 found in the official website of Ministry of Health of Indonesian Republic (kemenkes.go.ig) which have the English translation. It must be noted that the translation of articles provided in the website mostly cannot be accessed directly. Meanwhile the data of this research were clauses under the category of experiential function that experience a shift in transitivity.

This research adopts a qualitative method, which relies on linguistic data and non-numbers as basic analysis and problem solving. A qualitative research is a research procedure that generates descriptive data, which is not only produced in written or oral form by people, but also in an observed attitude. This research is a qualitative descriptive study, because this research aims to describe the transitivity shift found in the Translated Official Website of Ministry of Health of Indonesian Republic.

The data were collected by using the observation method, namely selecting the articles dealing with the Covid-19 and the English translation, reading carefully all the clauses in the source language, that is the Indonesian language, finding out the transitivity shift by classifying the sentences according to the experiential function.

After collecting the data, the research then is continued to the data analysis. The followings are steps conducting for analyzing the data, they are:

1) Reading the news related to Covid-19 including the source text (ST) written in Bahasa Indonesia and the target text (TT) provided in English.

2) Underlining or marking the clauses in the ST belonged experiential function as well as the TT. 
3) Classifying the marked clauses and their translations in the table.

4) Giving the code to each data.

5) Comparing the process contained in the clauses both in the ST and TT.

6) Analysing the transitivity shifts found.

7) Describing how the transitivity shifts are used in the translation.

\section{FINDINGS AND DISCUSSION}

This examination has gotten discoveries about the sorts of transitivity shifts utilized in the Translated Official Website of the Ministry of Health of Indonesia Republic and the translation. The subject of this examination is most famous articles in the Official Website of the Ministry of Health of Republic Indonesia.

\section{Findings}

The article is introduced in two languages, Bahasa Indonesia (ST) and English (TT). Specialists have chosen two of the most well-known articles and numerous perusers on the site. Both articles discussed about Covid-19 entitled Rules of Childbirth in COVID-19 Pandemic (Begini Aturan Persalinan di Masa Pandemi COVID-19) and Healthy Cycling in Covid-19 Pandemic Situation (Cegah Penularan, Begini Cara Gowes Sehat Di Tengah Pandemi COVID-19). Examination finding is talked about in two focuses: the sorts of transitivity shifts and the process of transitivity shifts.

In the wake of directing exploration and getting research finding about the sorts of transitivity move and how the process of transitivity shift is acknowledged, specialists at last arrived at the conversation stage. At the conversation stage analysts attempted to interface between research discovering, master hypotheses and the examination inquiries in any case. There are two discussion inquiries in this investigation, that are sorts of transitivity shifts are found in the texts Official Website of Indonesian Ministry of Health and transitivity shifts are acknowledged in the texts Official Website of Indonesian Ministry of Health. Subsequently the conversation on this exploration is isolated into two, in particular the sorts of transitivity shifts are found in the Translated Official Website of the Ministry of Health of Indonesian Republic and the process of transitivity shifts are acknowledged in the Translated Official Website of the Indonesian Ministry of Health.

The examination of sorts of transitivity shifts are found in the texts in Official Website of Indonesian Ministry of Health got the aftereffects of the kinds of

di) https://doi.org/10.52187/rdt.v2i2.48|125 
transitivity shift that happened in the translation from Bahasa Indonesia (ST) into English (TT) in an article on the site of the Kementrian Kesehatan. The outcomes showed that there are a few the transitivity shift in the articles. The transitivity shift in the analyzed articles, there are transitivity shifts one on existential to verbal, two on material to relational, one on behavioral to material, one on verbal to relational and one relational to existential. Nonetheless, there is no shift involving mental process in the two articles.

The six kinds of cycles are as per the assessment of Halliday (2002). Haliday brought up that there are six kinds of transitivity shifts, to be specific material process, mental process, relational process, behavioral process, verbal process and existential process. So this examination is upheld by the assessment of these specialists. The aftereffects of this investigation additionally got comparative outcomes as Rosa, Sofyan, and Tarigan (2018) who likewise tracked down these six kinds and material interaction ruled the discoveries. Along these lines, this exploration upholds with master speculations from Halliday (2002) and past research by Rosa, Sofyan, and Tarigan (2018).

Researcher gets how the cycle of transitivity shift happened in two articles about Covid 19 on the site of Indonesian Ministry of Health. The outcomes showed that there is importance between the aftereffects of the investigation and the hypothesis from Halliday (2002) about the transitivity shift measure, specifically Participants, Processes, and Circumstance. The process has its own specific manner of depicting a provision. In this investigation, it was expressed that Material process has participants Actor and Goal. Mental process has participants in the form of Senser and Phenomenon. Relational Process has participants in the form of Relational attributive: carrier, identifying: token Relational, attribute and possessed value. While Behavioral process has participants in the form of Behaver, Verbal process has participants in the form of Sayer and Receiver Verbiage, the last Existential process has a participant in the form of the existent. Circumstance use in this examination is circumstance place and time. So that this research based on Halliday theories.

\section{Discussion}

For evaluation of transitivity shift in the following result list was provided;

\section{Article 1:}

ST: Begini Aturan Persalinan di Masa Pandemi COVID-19 
TT: Rules of Childbirth in COVID-19 Pandemic

Clause 1

ST:

Aturan tersebut telah tercantum dalam surat edaran Direktorat Jenderal Pelayanan Kesehatan nomor HK.02.02/III/2878/2020 tentang Kesiapsiagaan Rumah Sakit Rujukan dalam Penanganan Rujukan Maternal dan Neonatal Dengan COVID-19

Existent Pro: Existential Circ. loc: Place

TT:

The acting Director said that the rules is included in the Circular General of Health Letter of Director General of Health Care Care, Abdul Kadir, Sayer Pro:Verbal Verbiage

Clause 1 showed Transitivity shift happens between existential and verbal process, at "telah tercantum" that is a Existential that has participant 1 as a existent and circumstance place at the end, which turns into a verbal with the participant 1 "Abdul Kadir" as sayer which is conveying a message to its objective beneficiary. "Said that" is remembered for the verbal due to the way toward saying and receiver verbiage at the end. In this way, the changes that happens in clause 1 lead to sentences that start as existential become verbal process.

Clause 2

ST:

perlu diterapkan protokol kesehatan bagi ibu hamil yang juga mempunyai risiko untuk menderita penyakit COVID-19.

Pro: Material Goal

TT:

\begin{tabular}{lll} 
it & is & $\begin{array}{l}\text { necessary to implement } \\
\text { health protocol for } \\
\text { pregnant women }\end{array}$ \\
\hline Carrier & $\begin{array}{l}\text { Pro: } \\
\text { Relational: } \\
\text { Attributive }\end{array}$ & Attribute \\
\hline
\end{tabular}

Clause 2 addressing the transitivity shift that occurs from material to relational process. Source text (ST) as material process that shows at "perlu diharapkan" 
because it is a reference to the way toward doing, while "is" in target text (TT) is viewed pro: relational:

Attributive because it depicts the condition. Participant in ST as a goal that shows at "protokol kesehatan" because it is participant which is a non-human in material process. In the mean time, first participant on the TT shows at "it"as a carrier and "health protocol" as attribute.

Clause 3

ST:

\begin{tabular}{|c|c|c|c|}
\hline $\begin{array}{l}\text { Setiap ibu } \\
\text { hamil yang } \\
\text { akan } \\
\text { melakukan } \\
\text { persalinan }\end{array}$ & Diimbau & $\begin{array}{l}\text { untuk } \\
\text { melakukan } \\
\text { skrining } \\
\text { COVID-19 }\end{array}$ & $\begin{array}{l}\text { tujuh hari } \\
\text { sebelum } \\
\text { taksir } \\
\text { persalinan. }\end{array}$ \\
\hline Behaver & $\begin{array}{l}\text { Pro: } \\
\text { Behavioral: } \\
\text { Verbal }\end{array}$ & $\begin{array}{l}\text { Circ. } \\
\text { Cause:reason }\end{array}$ & $\begin{array}{l}\text { Cir. } \\
\text { Time }\end{array}$ \\
\hline
\end{tabular}

TT:

\begin{tabular}{|c|c|c|c|}
\hline $\begin{array}{lr}\text { Every } & \text { pregant } \\
\text { woman } & \text { who is } \\
\text { about } & \text { giving } \\
\text { birth } & \\
\end{array}$ & is required & $\begin{array}{l}\text { to screen } \\
\text { COVID- } \\
19\end{array}$ & $\begin{array}{lr}\text { seven } & \text { days } \\
\text { before } & \text { the } \\
\text { estimated } & \text { date } \\
\text { of delivery } & \end{array}$ \\
\hline Goal & Material & $\begin{array}{l}\text { Cir. } \\
\text { Cause: } \\
\text { Reason }\end{array}$ & Cir. Loc: Time \\
\hline
\end{tabular}

Clause 3 addressing that the transitivity shift occurs from behavioral as a source text (ST) to material process as a target text (TT). ST has a behaver as a participant and TT has a goal at "every pregnant woman who is about giving birth " because it identifies with whom the way toward doing is focused on. ST is behavioral process. It can seen "diimbau" word, while TT as material process at "is required" because describe about doing something. ST and TT also have circumstance cause reason, namely "untuk melakukan skrining COVID-19" and "to screen COVID-19". ST and TT also have circumstance loc: time, namely "seven days before" and "tujuh hari sebelum tafsir persalinan". In this case, transitivity shift in clause 3 occurs from behavioral process to material process. 
Article 2:

ST: Cegah Penularan, Begini Cara Gowes Sehat Di Tengah Pandemi COVID-19

TT: Healthy Cycling in Covid-19 Pandemic Situation.

Clause 1

ST:

mengonsumsi. makanan bergizi seimbang, kelola stress, istirahat yang cukup, rutin olahraga termasuk aktivitas yang sangat dianjurkan

Pro: Material Goal

TT:

\begin{tabular}{|c|c|c|c|}
\hline $\begin{array}{l}\text { a balanced diet, stress } \\
\text { management, rest, } \\
\text { adequate } \\
\text { performing an exercise } \\
\text { or sports }\end{array}$ & Are & Significant & $\begin{array}{l}\text { as preventive } \\
\text { measures in Covid- } \\
19 \text { response. }\end{array}$ \\
\hline Carrier & $\begin{array}{l}\text { Relational: } \\
\text { Attributive }\end{array}$ & Attribute & Cir. Cause:Reason \\
\hline
\end{tabular}

Clause 1 shows transitivity shift that occur between material process and relational: Attributive process. Source text (ST) as a material process at "mengonsumsi" because it describes of doing something. While target text (TT) as a relational: attributive process at "are" that is talk about being. Then, participant on the ST as a goal at "makanan bergizi seimbang.." which is describe non-human. While Participant on the TT as a carrier at "A balanced diet..". "significant" as a attribute and "as preventive measures in Covid-19 response" as a cir. Cause reason. In this case, clause 1 there is a change in material process to relational process.

\section{Clause 2}

ST:

Ia menambahkan, saat ini edukasi dan diseminasi informasi
mengenai berolahraga yang baik dan benar harus
ditingkatkan.

TT: 


\begin{tabular}{lll}
$\begin{array}{l}\text { Amid the pandemic situation, Are } \\
\text { campaign and information }\end{array}$ & essential. \\
$\begin{array}{l}\text { dissemination on how to perform } \\
\text { proper exercise that conforms to }\end{array}$ & \\
health protocol & $\begin{array}{l}\text { Pro } \\
\text { Relational: } \\
\text { Attributive }\end{array}$ \\
\hline Carrier &
\end{tabular}

Clause 2 shows that there is transitivity shift between source text (ST) as a verbal process and target text (TT) as a relational process. ST has participant as a sayer, it can see at "ia" because the participant says something. Verbal process represent at "menambahkan" because it shows the participant needs to say something or explains something extra. TT has participant called carrier at "The Pandemic situation.." because it's non-human participants in the relational process. Relational in TT represent at "are" as a pro relational attributive and "essential" as a attribute. In this case, transitivity shift in clause 5 are ST as a verbal process and TT as a relational process.

Clause 3

ST:

\begin{tabular}{lll}
$\begin{array}{l}\text { Seiring dengan } \\
\text { banyaknya } \\
\text { pengguna, } \\
\text { aktivitas } \\
\text { bersepeda }\end{array}$ & & $\begin{array}{l}\text { sangat rawan akan } \\
\text { penyebaran COVID- } \\
19 .\end{array}$ \\
\hline Carrier & & \\
& $\begin{array}{l}\text { Pro Relational: } \\
\text { Attributive }\end{array}$ & Attribute \\
\hline
\end{tabular}

TT:

\begin{tabular}{ll} 
there is & $\begin{array}{l}\text { a significant increase in the number of } \\
\text { cyclists, communities, and events that } \\
\text { posed a threat of transmission of Covid- } \\
19\end{array}$ \\
\hline Pro: Existential & Existent
\end{tabular}

Clause 3 shows transitivity shift occurs between source text (ST) as relational process and target text (TT) as existential process. ST has participant 1 as an carrier at "aktivitas bersepeda.." . Relational process in ST represented by "menjadi" that talking about being. At the ends "..penyebaran covid-19" as participant 2 called the attribute. Meanwhile, existential process on the TT represented by "is" which shows something exist and followed by "a significant increase.." is something 
that occurs as the existent. In this case, transitivity shift in clause 6 are ST as attributive process and TT as existential process.

Clause 4

ST:

\begin{tabular}{llll}
$\begin{array}{l}\text { Penggunaan } \\
\text { masker saat } \\
\text { berolahraga } \\
\text { misalnya }\end{array}$ & Ia & $\begin{array}{l}\text { menegaskan } \\
\text { bahwa }\end{array}$ & $\begin{array}{l}\text { hal tersebut tidak akan } \\
\text { menganggu kegiatan } \\
\text { olahraga itu sendiri. }\end{array}$ \\
\hline Cir. Matter & Sayer & Pro: Verbal & Verbiage \\
\hline
\end{tabular}

TT:

\begin{tabular}{lllc}
$\begin{array}{l}\text { Mask wearing during } \\
\text { exercise }\end{array}$ & $\begin{array}{l}\text { will } \\
\text { protect }\end{array}$ & $\begin{array}{l}\text { people against Covid-19 especially in } \\
\text { transmission } \\
\text { crowded } \\
\text { places. }\end{array}$ \\
\hline Actor & Material & Goal & $\begin{array}{c}\text { Cir. Loc: } \\
\text { Place }\end{array}$ \\
\hline
\end{tabular}

Clause 4 shows transitivity shift between source text and target text. ST in this clause as a verbal process that represented by "menegaskan" because it incorporates the assertion interaction. Meanwhile, TT as a material process that represented by "will protect" because it shows about process of doing. ST has cir. Matter "penggunaan masker saat berolahraga misalnya,". It has participant 1 as a sayer represented by "ia" because it shows about someone that needs to say something and it has participant 2 as a verbiage, while TT has participant 1 as an actor represented by "Mask wearing during exercise" and participant 2 as a goal. Therefore, transitivity shift occurs between ST as a verbal process and TT as a material process.

\section{CONCLUSION}

This examination is a descriptive qualitative research which aims to find out the kinds of transitivity shifts used on the texts Official Website of Indonesian Ministry of Health and to investigate how those transitivity shifts are acknowledged on the texts Official Website of Indonesian Ministry of Health. By deciphering source text (ST) in Indonesian and target text (TT) in English. The subjects of exploration are the two most well known articles about Covid-19 on the official website of Indonesian Ministry of Health. This examination is depends on the theory from Halliday (2002) about the kinds of transitivity shift.

do) https://doi.org/10.52187/rdt.v2i2.48|131 
The aftereffects of this examination demonstrate that there are six sorts of transitivity shifts that happen in the interpretation of ST to TT. These types are (1) material process, (2) mental process, (3) relational process, (4) behavioral process, (5) verbal process and (6) existential process. The results showed that there are several the transitivity shift in the articles. The transitivity shift in the analyzed articles, there are transitivity shifts one on existential to verbal, two on material to relational, one on behavioral to material, one on verbal to relational and one relational to existential. Nonetheless, there is no shift involving mental process in the two articles.

\section{REFERENCES}

Halliday, M. A. K. (2002). An Introduction to Functional Grammar (2nd edition). London: Arnold.

Rahmawati, Y. R. (2018). An Analysis of Experiential Structure of Post-Modifier Translation in Nominal Group and Its Impact on the Translation Quality in To Bee or Not To Bee Book by John Penberthy. Prasasti: Journal of Linguistics, 3(2), 244-260. https://doi.org/https://doi.org/10.20961/prasasti.v3i2.8528

Rosa, R. N., Sofyan, R., \& Tarigan, B. (2018). Transitivity Analysis Of The Translation of Student Translators. Seventh International Conference on Languages and Arts (ICLA 2018), 606-612. Retrieved from https://www.atlantis-press.com/article/55914560.pdf

Sabrina, N. (2015). Pergeseran Makna dalam Penerjemahan dari Bahasa Inggris kedalam Bahasa Indonesia pada Teks Perjanjian Internasional di Bidang Pertahanan. Jurnal Linguistik Terapan, 5(2), 29-38. Retrieved from http://jlt.polinema.ac.id/index.php/jlt/issue/view/20/JLT Volume 5 No 2\%2C 2015

Tinambunan, M. F., Santoso, D., \& Tangkas, W. D. (2019). Transitivity Shifts in Translating of the Novel Laskar Pelangi into English. 4th Annual International Seminar on Transformative Education and Educational Leadership (AISTEEL 2019), 132-134. Atlantis Press SARL. Retrieved from https://www.atlantispress.com/article/125928352.pdf

Tzou, Y.-Z., Vaid, J., \& Chen, H.-C. (2017). Does formal training in translation/interpreting affect translation strategy? Evidence from idiom translation. Bilingualism: Language and Cognition, 20(3), 632-641. https://doi.org/https://doi.org/10.1017/S1366728915000929 
Whyatt, B., Stachowiak, K., \& Kajzer-Wietrzny, M. (2016). Similar and different: cognitive rhythm and effort in translation and paraphrasing. Poznan Studies in Contemporary Linguistics, 52(2), 175-208.

https://doi.org/https://doi.org/10.1515/psicl-2016-0007 